\section{Pentaclethra macroloba tannins fractions active against methicillin-resistant staphylococcal and Gram-negative strains showing selective toxicity}

\author{
Ivana Correa Ramos Leal, ${ }^{*}$ I Ivaldo I. Júnior, ${ }^{1}$ Eliezer M. \\ Pereira, ${ }^{2}$ Marinella da S. Laport, ${ }^{3}$ Ricardo M. Kuster, ${ }^{1}$ Kátia \\ Regina Netto dos Santos ${ }^{3}$
}

${ }^{\text {I}}$ Faculdade de Farmácia, Pólo Universitário, Universidade Federal do Rio de Janeiro, Campus Macaé, Brazil,

${ }^{2}$ Laboratório de Microbiologia, Instituto Federal de Educação, Ciência e Tecnologia do Rio de Janeiro, Campus Maracanã, Brazil,

${ }^{3}$ Instituto de Microbiologia Prof. Paulo de Góes, Centro de Ciências da Saúde, Universidade Federal do Rio de Janeiro, Brazil.
Revista Brasileira de Farmacognosia Brazilian Journal of Pharmacognosy 21(6): 991-999, Nov./Dec. 2011

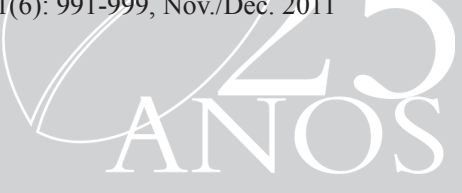

\section{Article}

Received 20 Sep 2010

Accepted 12 Jan 2011

Available online 5 Aug 2011

\begin{abstract}
The ethanol extract of the vegetal species Pentaclethra macroloba (Willd.) Kuntze, Fabaceae, was fractioned and the antibacterial activity was determined. The active ethyl acetate (ea) fraction showed activity against Gram-positive (Staphylococcus spp. and Enterococcus spp.) and Gram-negative (Pseudomonas aeruginosa, Acinetobacter spp. and Klebsiella pneumoniae) multiresistant bacteria. Gallic acid derivatives were identified as the main compounds in inactive subfractions from the ea fraction, while the active one afforded ellagic acid as the major constituent when submitted to acid hydrolysis reaction, which suggests the presence of hydrolysable tannins. The minimum bactericidal concentration analysis showed a bactericide mechanism of action for the tannin subfraction found. The antibacterial mechanism of action of the active tannin subfraction against $S$. aureus reference strains (ATCC 29213 e 33591) was proposed adopting an in vitro assay of protein synthesis inhibition. For this, bacterial cells were labeled with $\left[{ }^{35} \mathrm{~S}\right]$ methionine in the presence of the subfraction. The protein synthesis inhibition was observed at $256 \mu \mathrm{g} / \mathrm{mL}$ of this subfraction. At this concentration it did not present cytotoxicity in eukaryotic cells by the neutral red technique, suggesting selective toxicity. The present study is the first in vitro investigation of the antibacterial properties of tannin fractions obtained from a polar extract of P. macroloba.
\end{abstract}

Keywords: antibacterial activity cytotoxicity activity Gram-negative Pentaclethra macroloba protein synthesis Staphylococcus spp

ISSN 0102-695X http://dx.doi.org/10.1590/S0102$695 \times 2011005000132$

\section{Introduction}

Staphylococcus spp. is considered the leading cause of nosocomial infections worldwide (Deleo \& Chambers, 2009). In Brazil, methicillin-resistant Staphylococcus aureus (MRSA) is responsible for approximately $43 \%$ of these infections (Sader et al., 2004). Coagulase-negative staphylococci (CNS) is also recognized as a important nosocomial pathogen around the world, highlighting the multiresistant Staphylococcus epidermidis and Staphylococcus haemolyticus as the most isolated organisms from bacteremia (Nunes et al., 2007) and infections related to implanted medical devices (Uçkay et al., 2009) Resistance to methicillin is relevant in these pathogens because is related to resistance to other $\beta$-lactams and can be associated with resistance to other classes of antimicrobials (Feng et al., 2008).
It is also important to note the increasing incidence of infections caused by Gram-negative bacteria, including Acinetobacter spp. and Pseudomonas spp. resistant to carbapenems (Kokis et al., 2005; Touati et al., 2009). The prevalence of antimicrobial resistant isolates has increasing (Hsueh et al., 2002) as described recently by Touati and colleagues (2009) that assigned a mortality rate of $32 \%$ among neonates caused by multiresistant Acinetobacter baumannii.

The performance of in vitro studies of the activity of medicinal plants extracts against resistant pathogenic bacteria has increased in microbiology and has emerging as a scientific field of extreme interest. Pentaclethra macroloba (Wild.) Kuntze, Fabaceae, also popularly known as "sangredo", has a wide distribution at the region between Nicaragua and the Amazon, including the Guianas (Viana et al., 2004a). 
The bark of this species is a rich source of condensed tannins and phenolic compounds (Schedlbauer \& Kavanagh, 2008), chemical classes already recognized in the literature by exhibiting antimicrobial activities (Machado et al., 2002). Triterpenic monodesmoside saponins have already been found as major compounds in this species (Viana et al., 2004b). These compounds have shown anti-hemorrhagic activity, justifying the use of $P$. macroloba against bites from snakes (Silva et al., 2005). Extracts prepared from the seeds and bark of this species have also several uses in folk medicine, as healing of ulcers and dermal healing post cesarian (Silva et al., 2005).

The increasing prevalence of multiresistant bacteria, especially Gram-positive bacteria, such as Staphylococcus spp. (Nunes et al., 2007; NascimentoCarvalho et al., 2008), and Gram-negative bacilli (Kokis et al., 2005; Hsueh et al., 2002; Touati et al., 2009; Nogueira et al., 2006) can make difficult the treatment of infectious diseases. Then, as a new therapeutic option we evaluated the antibacterial activity of $P$. macroloba extracts against Gram-positive and Gram-negative hospital bacteria as well as against reference strains, establishing the minimum inhibitory activity of the active fractions. In addition, we intended to propose a mechanism of action of the active fraction based on the protein synthesis inhibition assay and examined the in vitro toxicity to eukaryotic cell cultures. The chemical composition of the active and the inactive fractions were also determined.

\section{Materials and Methods}

\section{Plant material}

The pulverized powder of the bark of Pentaclethra macroloba (Wild.) Kuntze, Fabaceae, was provided by the Prof. Dr. Walter Baptista Mors (NPPNUFRJ) in 2006. A copy of the individual can be found in the Research Institute of the Botanical Garden of Rio de Janeiro, in section 20 of the D site and is registered under number 4284 .

\section{Extraction and fractionation}

A total of $1 \mathrm{~kg}$ of the powdered stem bark of $P$. macroloba was extracted with ethanol at room temperature for five days, and the macerate was concentrated in rotary evaporator to obtain the dry crude ethanolic extract (ce) (92g). The resulting extract was suspended in $300 \mathrm{~mL}$ of methanol/water $\left(\mathrm{MeOH}: \mathrm{H}_{2} \mathrm{O}\right.$, 9:1) and then submitted to a liquid-liquid partition with $n$-hexane (3x $200 \mathrm{~mL})$. The separated aqueous $\mathrm{MeOH}$ layer was evaporated under reduced pressure and then resuspended in water. The resulting aqueous solution was extracted with solvents of increasing polarity $(3 \mathrm{x}$ $200 \mathrm{~mL}$ each one): dichloromethane $(d l)$, ethyl acetate (ea) and butanol (bu).

The ethyl acetate fraction $(1.77 \mathrm{~g})$ was fractioned using Sephadex LH-20 (Pharmacia) chromatography column and isocratic methanol solvent system as mobile phase (flow rate: $5 \mathrm{~mL} / \mathrm{min}$ ). The 200 (1-200) subfractions obtained (30 mL each) were grouped into seven major subfractions $\left(\mathrm{F}_{\mathrm{A} 1}\right.$ to $\left.\mathrm{F}_{\mathrm{A} 7}\right)$, according to the similarity of spots in silica gel thin layer chromatography (TLC) $\left(60 \mathrm{~F}_{254}\right.$, Merck) using different mobile phases, such as: dichloromethane:ethyl acetate:ethanol (2:0.4:0.3); ethyl acetate:ethanol:water $(12: 1: 0.5)$ and dichloromethane:methanol:water $(6: 3: 0.1)$.

\section{High performance liquid chromatography (HPLC) analysis}

In order to establish the chemical difference between the subfractions $\mathrm{F}_{\mathrm{A} 1}$ (bioinactive) and $\mathrm{F}_{\mathrm{A} 5}$ (bioactive) they were analyzed by an HPLC equipped with a Shimadzu LC-10AD pump and a CBM-10A photodiode array detector with absorptions from 200 to $500 \mathrm{~nm}$. The stationary phase was constituted by a RP18 column ( $5 \mu \mathrm{m}, 20 \times 5 \mathrm{~mm}$, Merck) and the mobile phase by an isocratic system of $0,5 \% \mathrm{H}_{3} \mathrm{PO}_{4}+0,01 \mathrm{M}$ $\mathrm{KH}_{2} \mathrm{PO}_{4}+\mathrm{CH}_{3} \mathrm{CN}(4: 4: 2)$ or a gradient elution protocol varying from 30 to $70 \%$ of $\mathrm{B}(\mathrm{MeOH})$ in $\mathrm{A}\left(\mathrm{H}_{2} \mathrm{O} / 0,01 \mathrm{M}\right.$ $\mathrm{H}_{3} \mathrm{PO}_{4}$ ) during $40 \mathrm{~min}$.

\section{Gas chromatography coupled to mass detector (GC-} MS)

The gas chromatography analysis of the volatile subfraction $\mathrm{F}_{\mathrm{A} 1}$ was performed on a Shimadzu GC-17A with interface GCMS-QP5000 and electronic impact correspondent to $70 \mathrm{ev}$. The database available for spectra comparison was the NIST (National Institute of Standards and Technology) from 1990.

\section{Bacterial strains}

The ethanol (ce), ethyl acetate (ea) and butanol (bu) fractions from $P$. macroloba were evaluated for antibacterial activity against fourteen clinical strains of $S$. aureus, being ten MRSA and four MSSA (methicillin-sensitive $S$. aureus). Two reference strains, ATCC 29213 (MSSA) and ATCC 33591 (MRSA) were also analyzed. Activities against nine strains of CNS, including four strains of $S$. epidermidis (three clinical and one ATCC 12228), four of S. haemolyticus (three clinical and one ATCC 29970) and one clinical strain of Staphylococcus hominis were also investigated.

Gram-negative bacteria considered for 
investigation were two reference strains of Klebsiella pneumoniae (ATCC 4352, a extended-spectrum $\beta$-lactamase (ESBL) producer and 700603), one reference strain of Pseudomonas aeruginosa (ATCC 27853), as well as thirty clinical isolates of this species. Among Acinetobacter spp. isolates 26 were evaluated, being nine $A$. baumanni resistant to carbapenems and one Acinetobacter lwoffii sensitive to them. Al the bacterial isolates used in the study were obtained from clinical specimens from patients in hospitals in Rio de Janeiro, Brazil.

\section{Minimal inhibitory concentration (MIC) determination}

To determine the minimal inhibitory concentration (MIC) of the active fraction and subfractions of $P$. macroloba against the bacterial strains listed above, it was used the Müeller Hinton agar (Difco) dilution technique according to CLSI (2003). Concentrations ranging from 64 to $512 \mu \mathrm{g} / \mathrm{mL}$ were used for the extract or each (sub) fraction tested. The bacterial inoculum was adjusted to approximately 104 colony-forming units $(\mathrm{CFU} / \mathrm{mL})$ and was added to the medium using a Steers replicator (Machado et al., 2005). The plates were incubated at $35{ }^{\circ} \mathrm{C}$ during $24 \mathrm{~h}$. The MIC values were calculated as the lowest concentration of extract or (sub) fraction where there was no bacterial growth. The antimicrobial oxacillin (Sigma) was used as control.

\section{Minimal bactericidal concentration determination}

In order to check the bactericidal vs. bacteriostatic action of the subfraction rich in tannins of P. macroloba $\left(\mathrm{F}_{\mathrm{A} 5}\right)$, $\mathrm{MBC}$ were determined against the reference strains ATCC 33591 e ATCC 29213. This technique establishes the smallest concentration (of those tested) of a drug necessary for the elimination of $99.9 \%$ of the microorganisms tested. The MBC was determined by the dilution method in broth (DMB) (CLSI, 2003). Initially, MIC value was determined by transferring $100 \mu \mathrm{L}$ from a bacterial suspension at $4-5 \mathrm{x}$ $10^{6} \mathrm{UFC} / \mathrm{mL}$ for tubes with the active subfraction $\left(\mathrm{F}_{\mathrm{A} 5}\right)$ in concentrations varying from 256 to $1024 \mu \mathrm{g} / \mathrm{mL}$ or with DMSO (solvent), used as a positive control. The inoculated tubes were incubated at $35^{\circ} \mathrm{C}$ during $24 \mathrm{~h}$ and the turbidity of each tube was analyzed after this period. The MBC value was determined after an aliquot of $100 \mu \mathrm{L}$ from tubes without growth was seeded on a Müller Hinton agar plate and incubated for $24 \mathrm{~h}$ at $35^{\circ} \mathrm{C}$. If $\mathrm{MIC}=\mathrm{MBC}$ value or if the $\mathrm{MBC}$ was up to two concentrations above the MIC, the compound was considered as bactericidal (Isenberg, 1992).
Protein synthesis analysis by SDS-PAGE in the presence of the subfraction $F_{A 5}$

The evaluation of the interference of $\mathrm{F}_{\mathrm{A} 5}$ in the protein synthesis of staphylococcal strains was performed according to Pereira and colleagues (2006). Initially, the inocula of the reference strains were carried out in $3 \mathrm{~mL}$ tubes of TSB (Trypticase soy broth, Oxoid) and then incubated under agitation for $24 \mathrm{~h}$. Then, a $0.5 \mathrm{~mL}$ aliquot from each solution was transferred into a tube with $2.5 \mathrm{~mL}$ of a new TSB and once incubated under agitation for 1 h. Briefly, $1.5 \mathrm{~mL}$ was transferred to an Eppendorff ${ }^{\circledR}$ tube that was centrifuged and suspended in a culture medium methionine-free (Free Mem, Gibco). Further, $200 \mu \mathrm{ci} / \mathrm{mL}$ of radioactivity labeled methionine $\left[{ }^{35} \mathrm{~S}\right]$ (Amershan) were added. To this solution, the $\mathrm{F}_{\mathrm{A} 5}$ was added at 250 and 125 $\mu \mathrm{g} / \mathrm{mL}$. After a treatment with lisostafin the samples were analyzed by sodium dodecyl sulfate polyacrylamide gel electrophoresis (SDS-PAGE) and further exposed to X-ray film.

\section{Cytotoxicity test}

The cytotoxicity test was carried out in order to determine in which concentration $\mathrm{F}_{\mathrm{A} 5}$ was toxic to eukaryotic cells and to compare the minimum inhibitory concentration (MIC) to this result. The test was performed according to Pereira et al. (2006). Briefly, cell line BSC-40 from kidney of African green monkey was propagated in microplates for $24 \mathrm{~h}$ in an ideal medium. Then, there were added $200 \mu \mathrm{L}$ of $\mathrm{F}_{\mathrm{A} 5}$ in a concentration greater than twice the value of MIC previously established. From the initial concentration there were established seven successive dilutions and twelve replicates of each. We then included two controls without fraction $\mathrm{F}_{\mathrm{A} 5}$ : the first one with DMSO, used as solvent for the fraction, and in the second, only the culture medium. After $24 \mathrm{~h}$ of incubation of the microplates, we observed the morphology of the cells by microscopy. Then there were added $100 \mu \mathrm{L}$ of neutral red $(0.1 \%)$ in each well and the microplates were incubated for $3 \mathrm{~h}$, washed and once incubated for fixing the dye. For neglecting the non-viable cells, it was added $100 \mu \mathrm{L}$ of a solution of $50 \%$ methanol and $1 \%$ acetic acid to each well and the plates were incubated. The optical density was measured at $490 \mathrm{~nm}$ using a microtiter plate Spectrophotometer. The uptake of neutral red is proportional to the number of viable cells (Isenberg, 1992).

\section{Results and Discussion}

Chromatographic analysis of the subfractions $F_{A 1}$ and $F_{A 5}$ 


\section{Subfraction $\mathrm{F}_{\mathrm{A} 5}$}

The highest bacterial inhibitory activity was found in the subfraction $\mathrm{F}_{\mathrm{A} 5}$ obtained from the $e a$ fraction. So, this subfraction was submitted to an analysis by HPLC-DAD, which indicated the presence of a major peak with UV spectra characteristic of phenolic substances (204 and $275 \mathrm{~nm}$ ). This fraction was subjected to a hydrolysis reaction with an aqueous solution of $1 \mathrm{~N} \mathrm{HCl}, 30 \mathrm{~min}$ and further re-analyzed by HPLC-DAD. A major signal with the same retention time (32.94 $\mathrm{min})$ and UV spectrum of a standard of ellagic acid was observed, suggesting the presence of an ellagitannin (polihydroxylated phenolic substance). Both, ellagic acid standard and the product of hydrolysis of $\mathrm{F}_{\mathrm{A} 5}$, presented maximum absorbances at 254 and $366 \mathrm{~nm}$. The ellagic acid (1) is formed from the condensation of two gallic acid units, originating a residue knowing as hexahydroxidiphenoil (HHDP) (2) (Tanaka et al., 2003).

\section{Subfraction $\mathrm{F}_{\mathrm{A} 1}$}

In the HPLC chromatogram two major peaks around 3.98 and $5.65 \mathrm{~min}$ (Figure 1) were observed. The UV spectra of the major constituents present in the subfraction $\mathrm{F}_{\mathrm{A} 1}$ suggested the presence of substances with absorbance peaks characteristic of benzoic acids (215, 261 and $292 \mathrm{~nm})$. The results were confirmed beyond the analysis by GC-MS further methylation reaction with diazomethane. The substances were identified as being the protocatecuic acid derivatives: gallic acid methyl ester (3,4,5-trimetoxi-benzoic acid) (3), important in the biosynthesis of hydrolysable tannins and, in a minor amount, the 3,4-dimethoxy benzoic acid (4).

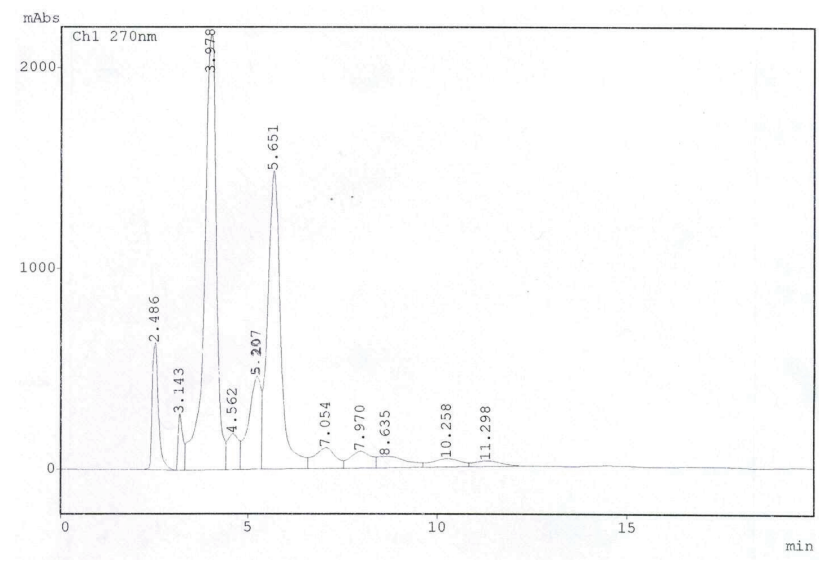

Figura 1. HPLC chromatogram of the subfraction $F_{A}$ obtained from the ethyl acetate fraction of the vegetal specie P. macroloba (silicagel RP-18, 0,5\% $\mathrm{H}_{3} \mathrm{PO}_{4}+0,01 \mathrm{M} \mathrm{KH}_{2} \mathrm{PO}_{4}$ $\left.+\mathrm{CH}_{3} \mathrm{CN}-4: 4: 2\right)$
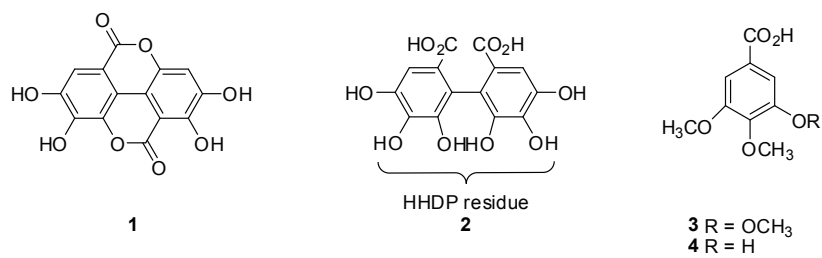

Antibacterial activity analysis of the fractions and subfractions

bu)

Antibacterial analysis of the fractions (ce, ea and

The ce, ea and bu fractions were primarily assayed against the strains described in the Table 1. At this assay the following concentrations: 500, 250, 125 and $62.5 \mu \mathrm{g} /$ $\mathrm{mL}$ were tested. At $125 \mu \mathrm{g} / \mathrm{mL}$ the ea fraction inhibited around $50 \%$ of the coagulase-negative staphylococci (CNS) as well as four clinical isolates of $S$. aureus, three MRSA and one MSSA. The other fractions did not show activity at this concentration.

At $250 \mu \mathrm{g} / \mathrm{mL}$, all MRSA, MSSA and CNS strains were susceptible to the ea fraction. At this concentration, the inhibition by the $b u$ fraction was less pronounced since just six from the sixteen strains of the $S$. aureus and four from the nine strains of CNS were inhibited. The ce fraction presented an unsatisfactory result once only three from the sixteen strains of $S$. aureus tested and one from the nine strains of CNS were inhibited.

At the major concentration investigated (500 $\mu \mathrm{g} / \mathrm{mL}$ ) both, ce and ea, were able to inhibit all MRSA, MSSA and CNS strains assayed. However, only the last one was capable to promote inhibitory activity against the Gram-negative reference strains of $K$. pneumoniae (ATCC 700603 ) and of $P$. aeruginosa (ATCC 27853). So, beyond the primary results obtained it was possible to observe that the ea fraction, wealthy in tannins, exhibited the best antibacterial performance.

The extract and fractions were also investigated against one ATCC and 29 hospital strains of $P$. aeruginosa (fourteen resistant and fifteen sensitive to carbapenem). The results showed that just the ea fraction, at $500 \mu \mathrm{g} /$ $\mathrm{mL}$, was active against $P$. aeruginos $a$ clinical isolates. The inhibition percentage observed was around $70 \%$ of thirty strains evaluated, considering that nine out of fourteen resistant to the carbapenems were inhibited.

The fractions ce, ea and $b u$ from P. macroloba were also investigated against 26 clinical strains of Acinetobacterspp. and one strain of $A$. lwoffii (sensitivity to carbapenem) in two different concentrations (250 and $500 \mu \mathrm{g} / \mathrm{mL}$ ). At $250 \mu \mathrm{g} / \mathrm{mL}$, just one strain of $A$. baumanni (resistant to carbapenem) and the strain of $A$. lwoffii were inhibited by the ea fraction, nevertheless, at $500 \mu \mathrm{g} / \mathrm{mL}$, almost all the strains investigated showed 
Table 1. Minimun inhibitory concentration (MIC) results obtained for Pentaclethra macroloba extracts against 29 bacterial strains

\begin{tabular}{|c|c|c|c|c|}
\hline \multirow{2}{*}{ Bacterial species } & \multirow{2}{*}{ Strain Number } & \multicolumn{3}{|c|}{ P. macroloba extract and fractions MIC* } \\
\hline & & $c e$ & $e a$ & $b u$ \\
\hline \multirow[t]{11}{*}{ S. aureus (MRSA) } & $2 \mathrm{a}$ & 500 & 250 & 500 \\
\hline & $5 \mathrm{a}$ & 500 & 250 & 500 \\
\hline & $4 a$ & 500 & 250 & 500 \\
\hline & $14 \mathrm{a}$ & 500 & 125 & 250 \\
\hline & $26 \mathrm{a}$ & 250 & 250 & 500 \\
\hline & $73 a$ & 250 & 250 & 250 \\
\hline & $77 \mathrm{a}$ & 500 & 125 & 250 \\
\hline & $80 \mathrm{a}$ & 500 & 125 & 250 \\
\hline & $90 \mathrm{a}$ & 500 & 250 & 500 \\
\hline & $102 \mathrm{a}$ & 500 & 250 & 500 \\
\hline & ATCC 33591 & 500 & 250 & 500 \\
\hline \multirow[t]{5}{*}{ S. aureus (MSSA) } & $246 \mathrm{a}$ & 500 & 250 & 500 \\
\hline & $247 \mathrm{a}$ & 500 & 250 & 500 \\
\hline & $249 \mathrm{a}$ & 500 & 250 & 250 \\
\hline & $253 a$ & 500 & 125 & 250 \\
\hline & ATCC 29213 & 250 & 250 & 500 \\
\hline \multirow[t]{5}{*}{ S. epidermidis } & $25 \mathrm{~s}^{\dagger}$ & 500 & 250 & 500 \\
\hline & $27 \mathrm{~s}^{\dagger}$ & 500 & 250 & 500 \\
\hline & $29 \mathrm{~s}^{\dagger}$ & 500 & 125 & 250 \\
\hline & $126 \mathrm{~s}$ & 250 & 125 & 250 \\
\hline & ATCC 12228 & 500 & 125 & 250 \\
\hline S. hominis & $41 \mathrm{~s}$ & 500 & 250 & $>500$ \\
\hline \multirow[t]{3}{*}{ S. haemolyticus } & $85 \mathrm{~s}$ & 500 & 250 & $>500$ \\
\hline & $99 \mathrm{~s}^{\dagger}$ & 500 & 250 & 500 \\
\hline & ATCC 29970 & 500 & 125 & 250 \\
\hline E. faecalis & ATCC 29212 & $>500$ & 500 & $>500$ \\
\hline \multirow[t]{2}{*}{ K. pneumoniae } & ATCC 700603 & $>500$ & 500 & 500 \\
\hline & ATCC 4352 & $>500$ & $>500$ & $>500$ \\
\hline P. aeruginosa & ATCC 27853 & $>500$ & 500 & 500 \\
\hline
\end{tabular}

*MIC-Minimum inhibitory concentration in $\mu \mathrm{g} / \mathrm{mL}$; ce: crude extract; ea: ethyl acetate and bu: buthanol; MSSA-Methicillin-susceptible $S$.aureus; MRSA-methicillin-resistant S.aureus; 'ंmethicillin-resistant coagulase-negative staphylococci.

susceptibility to this fraction. Considering a total inhibition percentage, around $96.2 \%$ of the $A$. baumannii strains were inhibited by the ea fraction. The other fractions did not present activity, in exception, against the strain of $A$. lwoffii, that displayed susceptibility.

From the results obtained it was possible to observe, therefore, that the fraction ea was the single one capable to inhibit the major part of the Gram-negative strains. However, it is important to highlight that none of the fractions analyzed, even the ea fraction, was active against the beta-lactamase producer $K$. pneumoniae strain (ATCC 4352).
Antibacterial analysis of the subfractions obtained from the $e a$ fraction

The main subfractions obtained from the Sephadex column chromatography of the active ea fraction were investigated for its antibacterial properties against the same clinical and ATCC reference strains mentioned in section 2.5. The Table 2 presents the MIC for each subfraction evaluated. Four different concentrations $(500,250,125$ and $62.5 \mu \mathrm{g} / \mathrm{mL})$ were adopted for this analysis.

At $125 \mu \mathrm{g} / \mathrm{mL}$ the tannin subfraction $\mathrm{F}_{\mathrm{A} 5}$ inhibited five among sixteen strains of $S$. aureus and three among 
Table 2. Minimun inhibitory concentration (MIC) values attributed for the fractions obtained from the ea extracts of Pentaclethra macroloba against 29 bacterial strains.

\begin{tabular}{|c|c|c|c|c|c|c|c|c|}
\hline \multirow{2}{*}{ Bacterial species } & \multirow{2}{*}{ Strain Number } & \multicolumn{7}{|c|}{ P. filamentosa ea fractions MIC* } \\
\hline & & $\mathrm{F}_{\mathrm{A} 1}$ & $\mathrm{~F}_{\mathrm{A} 2}$ & $\mathrm{~F}_{\mathrm{A} 3}$ & $\mathrm{~F}_{\mathrm{A} 4}$ & $\mathrm{~F}_{\mathrm{A} 5}$ & $\mathrm{~F}_{\mathrm{A} 6}$ & $\mathrm{~F}_{\mathrm{A} 7}$ \\
\hline \multirow[t]{11}{*}{ S. aureus (MRSA) } & $2 \mathrm{a}$ & $>500$ & 250 & 500 & $>500$ & 250 & 250 & 500 \\
\hline & $5 \mathrm{a}$ & $>500$ & 250 & 250 & 500 & 250 & 250 & 250 \\
\hline & $4 \mathrm{a}$ & $>500$ & 250 & 250 & 500 & 250 & 250 & 250 \\
\hline & $14 \mathrm{a}$ & 500 & 125 & 125 & 500 & 125 & 125 & 250 \\
\hline & $26 \mathrm{a}$ & 500 & 125 & 125 & 500 & 125 & 250 & 250 \\
\hline & $73 a$ & 500 & 250 & 125 & 500 & 125 & 250 & 500 \\
\hline & $77 \mathrm{a}$ & 500 & 250 & 250 & 500 & 250 & 125 & 250 \\
\hline & $80 \mathrm{a}$ & 500 & 125 & 125 & 500 & 125 & 250 & 250 \\
\hline & $90 \mathrm{a}$ & $>500$ & 250 & 250 & $>500$ & 250 & 250 & 250 \\
\hline & $102 \mathrm{a}$ & 500 & 125 & 250 & 500 & 250 & 250 & 250 \\
\hline & ATCC 33591 & 500 & 250 & 250 & $>500$ & 250 & 250 & 250 \\
\hline \multirow[t]{5}{*}{ S. aureus (MSSA) } & $246 a$ & $>500$ & 250 & 500 & $>500$ & 250 & 250 & 500 \\
\hline & $247 \mathrm{a}$ & 500 & 125 & 125 & 500 & 250 & 250 & 500 \\
\hline & $249 \mathrm{a}$ & $>500$ & 250 & 250 & 500 & 250 & 250 & $>500$ \\
\hline & $253 a$ & 500 & 250 & 125 & 500 & 125 & 250 & 250 \\
\hline & ATCC 29213 & $>500$ & 250 & 500 & $>500$ & 250 & 250 & 500 \\
\hline \multirow[t]{5}{*}{ S. epidermidis } & $25 \mathrm{~s}^{\dagger}$ & $>500$ & 250 & 250 & $>500$ & 250 & 250 & 500 \\
\hline & $27 \mathrm{~s}^{\dagger}$ & $>500$ & 250 & 250 & $>500$ & 250 & 250 & 250 \\
\hline & $29 \mathrm{~s}^{\dagger}$ & $>500$ & 250 & 250 & $>500$ & 250 & 250 & 250 \\
\hline & $126 \mathrm{~s}$ & $>500$ & 125 & 125 & 500 & 125 & 125 & 250 \\
\hline & ATCC 12228 & $>500$ & 250 & 250 & $>500$ & 125 & 125 & 250 \\
\hline S. hominis & $41 \mathrm{~s}$ & $>500$ & 250 & 250 & $>500$ & 250 & 250 & 250 \\
\hline \multirow[t]{3}{*}{ S. haemolyticus } & $85 \mathrm{~s}$ & $>500$ & 250 & 500 & $>500$ & 250 & 250 & $>500$ \\
\hline & $99 \mathrm{~s}^{\dagger}$ & $>500$ & 250 & 250 & $>500$ & 250 & 250 & $>500$ \\
\hline & ATCC 29970 & $>500$ & 250 & 500 & $>500$ & 125 & 250 & 250 \\
\hline E. faecalis & ATCC 29212 & $>500$ & $>500$ & $>500$ & $>500$ & 500 & 500 & $>500$ \\
\hline \multirow[t]{2}{*}{ K. pneumoniae } & ATCC 700603 & $>500$ & $>500$ & $>500$ & $>500$ & 500 & 500 & $>500$ \\
\hline & ATCC 4352 & $>500$ & $>500$ & $>500$ & $>500$ & $>500$ & $>500$ & $>500$ \\
\hline P. aeruginosa & ATCC 27853 & $>500$ & $>500$ & 500 & $>500$ & 500 & 500 & $>500$ \\
\hline
\end{tabular}

*MIC: Minimum inhibitory concentration in $\mu \mathrm{g} / \mathrm{mL}$; MSSA-methicillin sensitive S.aureus; MRSA-methicillin resistant S.aureus; ${ }^{2}$ methicillin-resistant coagulase-negative staphylococci.

nine CNS strains. Among the subfractions analyzed, $\mathrm{F}_{\mathrm{A} 2}$ showed the most similar profile compared to $\mathrm{F}_{\mathrm{A} 5}$. The reminiscent subfractions presented moderate activity $\left(\mathrm{F}_{\mathrm{A} 3}\right.$ and $\left.\mathrm{F}_{\mathrm{A} 6}\right)$ or any inhibitory activity $\left(\mathrm{F}_{\mathrm{Al}}, \mathrm{F}_{\mathrm{A} 4}\right.$ and $\left.\mathrm{F}_{\mathrm{A} 7}\right)$. The other bacterial species were not inhibited at this concentration.

At $250 \mu \mathrm{g} / \mathrm{mL}$, the CNS and $S$. aureus strains were completely inhibited by the subfractions $\mathrm{F}_{\mathrm{A} 2}, \mathrm{~F}_{\mathrm{A} 5}$ and $\mathrm{F}_{\mathrm{A} 6}$ while the Gram-negative bacteria and the E. faecalis strain showed to be resistant. At the highest concentration investigated the Gram-negative bacteria, in exception the ATCC 4352 of K. pneumoniae, were inhibited by $\mathrm{F}_{\mathrm{A} 5}$ and $\mathrm{F}_{\mathrm{A} 6}$.
A variety of studies has been focusing on the development of antimicrobial resistance among hospital Gram-positive and Gram-negative bacteria. S. aureus, for example, exhibit a mechanism of action which protect them against almost all member of the largest family of antibiotics, the beta-lactams (ex. methicillin), which can be explained by presence of the gene mecA (Fey et al., 2003; Nascimento-Carvalho et al., 2008). P. aeruginosa has also presented increased resistance, including to imipenem, one of the antibacterial drugs with the largest spectrum of action against this pathogen (Kokis et al., 2005). Although there is found a variety of studies considering natural products as feasible antimicrobial agents against 
Staphylococcus (Machado et al., 2002; Machado et al., 2005; Pereira et al., 2006; Leal et al., 2010), investigations on the inhibition of Gram-negative bacteria by these products are poorly found in the literature, awakening the interest for this investigation. So, the search for new strategies for the treatment of infections caused by these pathogens stimulates the investigation of alternative sources (Machado et al., 2005). Accordingly, our findings in respect of the tannins subfraction as an antibiotic agent are of great relevance once this is the first report correlating the vegetal species studied with this property. We could realize that grand part of the clinical strains evaluated was inhibited by the phenolic fraction, considering both, Gram positive and negative strains.

Evaluation of the minimum bactericidal concentration of the subfraction $\mathrm{F}_{\mathrm{A} 5}$

A drug can be considered bactericidal in concentrations until two logs over that previously stipulated by the MIC. By the broth dilution method it was assigned a MIC at $256 \mu \mathrm{g} / \mathrm{mL}$ for the subfraction $\mathrm{F}_{\mathrm{A} 5}$ against the reference strain ATCC 29213 of $S$. aureus, so, higher concentrations up to $1024 \mu \mathrm{g} / \mathrm{mL}$ were evaluated. The results showed that at $256 \mu \mathrm{g} / \mathrm{mL} \mathrm{F}_{\mathrm{A} 5}$ was not able to promote a percentage of inhibition equivalent or higher than $99.9 \%$. Nevertheless, at 512 and $1024 \mu \mathrm{g} / \mathrm{mL}$ it was not observed any bacterial growth suggesting a bactericidal mechanism of action for the subfraction $\mathrm{F}_{\mathrm{A} 5}$.

Proposal of the antibacterial mechanism of action for the tannin subfraction $F_{A 5}$

Analysis of the bacterial protein synthesis in the presence of $\mathrm{F}_{\mathrm{A} 5}$

Based on the fact that tannins can act beyond the bacterial metabolic system, the interference of the tannin subfraction $\mathrm{F}_{\mathrm{A} 5}$ in the protein synthesis of the reference strains ATCC 29213 (MSSA) and ATCC 33591 (MRSA) of $S$. aureus was investigated. In this way, our group could propose a feasible antibacterial mechanism of action for the subfraction $\mathrm{F}_{\mathrm{A} 5}$.

For this analysis were selected two different concentrations of $\mathrm{F}_{\mathrm{A} 5}$, the MIC $250 \mu \mathrm{g} / \mathrm{mL}$ and the subMIC $125 \mu \mathrm{g} / \mathrm{mL}$ ones, established previously by the broth dilution method. The aiming was to correlate the inhibitory effect observed in the antibacterial test with the potential toxic effect in the protein synthesis. The subMIC concentration is important to appraise once it can show possible initial modifications in the protein synthesis profile when compared to the standard in the absence of $\mathrm{F}_{\mathrm{A} 5}$.

The autoradiogram (Figure 4) showed that in the presence of the subfraction $\mathrm{F}_{\mathrm{A} 5}(250 \mu \mathrm{g} / \mathrm{mL})$ the bacteria protein synthesis of the sensitive strain, as well as of the resistant strain ATCC 33591, was inhibited. On the contrary, it was possible to observe the incorporation of ${ }^{35} \mathrm{~S}-\mathrm{Met}$ in the protein synthesized by the control strains (in the absence of fraction $\mathrm{F}_{\mathrm{A} 5}$ ) as well as on that in the presence of the subfraction at $125 \mu \mathrm{g} / \mathrm{mL}$.

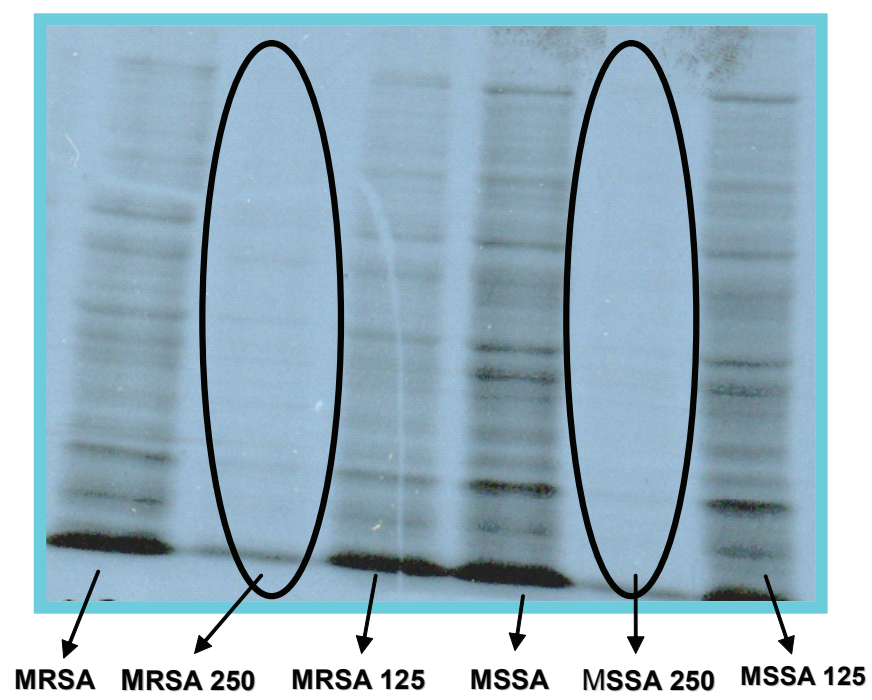

Figure 4. Analysis of staphylococcal protein synthesis. Autoradiogram of a SDS-PAGE protein profile of the strains ATCC 29213 (MSSA) and ATCC 33591(MRSA) of S. aureus labeled in the presence of $\left.{ }^{35} \mathrm{~S}\right]$ Met $(200 \mu \mathrm{Ci} / \mathrm{mL})$ at two concentrations of fraction $\mathrm{F}_{\mathrm{A} 5}$; MRSA: methicillin-resistant $\mathrm{S}$. aureus; MRSA 250: strain in the presence of $\mathrm{F}_{A 5}$ at $250 \mu \mathrm{g} / \mathrm{mL}$; MRSA 125: strain in the presence of FA5 at $125 \mu \mathrm{g} / \mathrm{mL}$; MSSA: Methicillin-susceptible S.aureus; MSSA 250: strain in the presence of $\mathrm{F}_{\mathrm{A} 5}$ at $250 \mu \mathrm{g} / \mathrm{mL}$; MSSA 125: strain in the presence of $\mathrm{F}_{\mathrm{A} 5}$ at $125 \mu \mathrm{g} / \mathrm{mL}$.

Our data illustrate the fact that in sub-MIC dosage is still not possible to verify, apparently, an inhibitory effect in the protein synthesis of the strains analyzed. These data correlate satisfactorily with the MIC values previously assigned by the broth dilution technique. Tannins are known by linking strongly to proteins, in vitro, and by forming a complex called "tannin-protein complex" (T-PC) considerably resistant to the degradation by digestive enzymes (Osawa, 1996). Therefore, one of the antimicrobial mechanisms of action of the tannins can be explained by the inhibition of the bacterial and fungi enzymes and/or by the formation of complexes with the substrates of them (Scalbert, 1991). Our results could presuppose that the ellagitannins, assigned for the first time as the major constituents in the active subfraction, would be acting by a protein synthesis inhibition mechanism probably beyond a tannin-protein complex as mentioned.

\section{Cytotoxicity}

In order to evaluate if there was specificity of the 
toxicological effect caused by $\mathrm{F}_{\mathrm{A} 5}$ in prokaryotic cells our group investigated the influence of the presence of this subfraction in different concentrations in the eukaryotic cell growth. The cytotoxicity assay was performed aiming to determine the subfraction concentration able to cause toxic effects in eukaryotic cells, comparing it with the bacterial MIC previously established.

The Figure 5 presents the correlation between the viable cells percentages of $\mathrm{F}_{\mathrm{A} 5}$ in relation to the control (absence of the fraction) when there were incorporated different concentrations of the referred subfraction. The results were assigned after 24 and $48 \mathrm{~h}$ of incubation. The measurements are presented as medium of the replicates. The cells were further observed by microscopy and it was possible to detect a slightly change in the cellular morphology at the two highest concentrations investigated (470 and $235 \mu \mathrm{g} / \mathrm{mL}$ ) of the subfraction $\mathrm{F}_{\mathrm{A} 5}$. However, it was not observed cellular killing. The data showed that in any concentration evaluated the subfraction investigated did not present cytotoxicity.

The data presented indicated that, at the MIC (250 $\mu \mathrm{g} / \mathrm{mL}$ ) against the clinical strains (MRSA and MSSA) as well as against the reference strains (ATCC 29213 and ATCC 33591) of S. aureus it was not observed toxicity for the cell culture analyzed. Even at a concentration one log over the MIC it was still not observed toxicity.

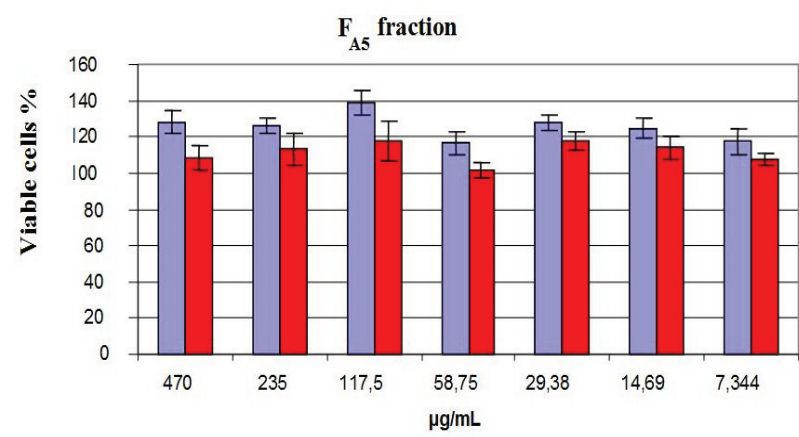

Figure 5. Cytotoxicity assay by the neutral red incorporation method. Eukaryotic cells (BSC-40) were grown as adherent culture in a 96-well microplate. The fraction $\mathrm{F}_{\mathrm{A} 5}$ was added at concentrations showed in the graphics (470 to $7.344 \mu \mathrm{g} / \mathrm{mL}$ ) for $24 \mathrm{~h}$. The relation between sample absorbance and control absorbance calculated the relative absorbance. The measurements are expressed as average of replicates.

Our results showed that in the MIC value the most active subfraction is not toxic for eukaryotic cells. This assay is extremely important once one of our future objectives is to suggest the use of the vegetal species $P$. macroloba as a constituent for a phytopharmaceutical to be used in the therapy against infections. So, our present results proved that the subfraction $\mathrm{F}_{\mathrm{A} 5}$ (ellagitannins) presented selective-toxicity for prokaryotic cells, as well as bactericidal effect against multiresistant bacterial of clinical importance.

\section{Conclusion}

The present study reports the first in vitro investigation about the antibacterial properties of tannin subfractions obtained from an ethyl acetate fraction of $P$. macroloba, enriching the research for natural products with relevant activity against clinical importance bacteria. This vegetal species has never been analyzed under this aspect. The data described in this work are in accordance with the literature which recognizes the tannins as healings. So, our results suggest the use of $P$. macroloba extract as a future phytopharmaceutical for the treatment of infectious diseases, however, further research is required to evaluate the practical value of this therapeutic application.

\section{Acknowledgement}

We are grateful to Marlei Silva for his assistance in the antibacterial experiment and to Professor Walter Baptista Mors for furnishing the exemplar of the plant. We thank Dr. Clarissa R Damaso and Desyree M Jesus (Instituto de Biofísica, UFRJ) for the cytotoxicity assay support. This study was supported by grants from Fundação Carlos Chagas Filho de Amparo à Pesquisa do Estado do Rio de Janeiro, Conselho Nacional de Desenvolvimento Científico e Tecnológico, Coordenação de Aperfeiçoamento Pessoal de Nível Superior and Programa de Núcleos de Excelência.

\section{References}

Clinical and Laboratory Standards Institute (CLSI) 2003. Methods for dilution antimicrobial susceptibility tests for bacteria that grow aerobically. Wayne, Pennsylvania, USA: Approved Standards:M7-A6.

DeLeo FR, Chambers HF 2009. Reemergence of antibioticresistant Staphylococcus aureus in the genomics era. $J$ Clin Invest 119: 2464-74.

Feng Y, Chen CJ, Su LH, Hu S, Yu J, Chiu CH 2008. Evolution and pathogenesis of Staphylococcus aureus: lessons learned from genotyping and comparative genomics. FEMS Microbiol Rev 32: 23-37.

Fey PD, Saïd-Salim B, Rupp ME, Hinrichs SH, Boxrud DJ, Davis CC, Kreiswirth BN, Schlievert PM 2003. Comparative molecular analysis of community- or hospital-acquired methicillin-resistant Staphylococcus aureus. Antimicob Agents Chemother 47: 196-203.

Hsueh PR, Chen ML, Sun CC, Chen WH, Pan HJ, Yang LS, Chang SC, Ho SW, Lee CY, Hsieh WC, Luh KT 2002. Antimicrobial drug resistance in pathogens causing nosocomial infections at a university hospital in Taiwan, 1981-1999. Emerg Infect Dis 8: 63-68.

Isenberg HD 1992. Antimicrobial susceptibility testing. Tests to assess bactericidal activity. In: Clinical Microbiology Procedures Handbook. Washington, D.C., USA: ASM Press.

Kokis VM, Moreira BM, Pellegrino FL, Silva MG, Long JB, Bastos CC, Santos KR 2005. Identification of an 
imipenem-resistant Pseudomonas aeruginosa clone among patients in a hospital in Rio de Janeiro. J Hosp Infect 60: 19-26.

Leal ICR, Dos Santos KRN, Júnior II, Antunes OAC, Porzel A, Wessjohann L, Kuster RM 2010. Ceanothane and lupane type triterpenes from Zizyphus joazeiro - an antiStaphylococcal evaluation. Planta Med 76: 47-52.

Machado TB, Leal ICR, Kuster RM, Santos KRN, Silva MG, Amaral ACF 2002. Antimicrobial ellagitannin of Punica granatum fruits. J Braz Chem Soc 13: 606-610.

Machado TB, Leal ICR, Kuster RM, Amaral ACF, Kokis V, Silva MG, Santos KRN 2005. Brazilian phytopharmaceuticals - evaluation against hospital bacteria. Phytother Res 19: 519-525.

Nascimento-Carvalho CM, Lyra TG, Alves NN, Caldas RM, Barberino MG 2008. Resistance to methicillin and other antimicrobials among community-acquired and nosocomial Staphylococcus aureus strains in a pediatric teaching hospital in Salvador, northeast Brazil. Microb Drug Resist 14: 129-131.

Nogueira K da S, Higuti IH, Do NAscimento AJ, Terasawa LB, De Oliveira S, Matos AP, Souza HAPM, Cogo LL, Dalla-Costa LM 2006. Occurrence of extended-spectrum beta-lactamases in Enterobacteriaceae isolated from hospitalized patients in Curitiba, southern Brazil. Braz J Infect Dis 10: 390-395.

Nunes APF, Schuenck RP, Bastos CCR, Magnanini MMF, Long JB, Iorio NLP, Dos Santos KRN 2007. Heterogeneous resistance to vancomycin and teicoplanin among Staphylococcus spp. solated from bacteremia. Braz J Infect Dis 11: 345-350.

Osawa RO 1996. Tannin-protein complex-degrading Enterobacteria isolated from the alimentary tracts of koalas and a selective medium for their enumeration. Appl Envir Microbiol 58: 1754-1759.

Pereira EM, Machado TB, Leal ICR, Jesus DM, Damaso CRA, Pinto AV, Giambiagi-de-Marval M, Kuster RM, Santos KRN 2006. Tabebuia avellanedae naphthoquinones: activity against methicillin-resistant staphylococcal strains, cytotoxic activity and in vivo dermal irritability analysis. Ann Clin Microbiol Antimicrob 5:5.

Sader HS, Jones RN, Gales AC, Silva JB, Pignatari AC, The Sentry Participants Group (Latin America) 2004. Sentry antimicrobial surveillance program report: Latin
American and Brazilian results for 1997 through 2001 Braz J Infect Dis 8: 25-79.

Scalbert A 1991. Antimicrobial properties of tannins. Phytochemistry 30: 3875-3883.

Schedlbauer JL, Kavanagh KL 2008. ${ }^{8} \mathrm{C}$ in Pentaclethra macroloba trees growing at forest edges in north-eastern Costa Rica. J Trop Ecol 24: 39-47.

Silva JO, Coppede JS, Fernandes VC, Sant'ana CD, Ticli FK, Mazzi MV, Giglio JR, Pereira PS, Soares AM, Sampaio SV 2005. Antihemorragic, antinucleolytic and other antiophidian properties of the aqueous extract from Pentaclethra macroloba. J Ethnopharmacol 100: 145152.

Tanaka T, Fukumori M, Ochi T, Kouno I 2003. Paeonianins A-E, new dimeric and monomeric ellagitannins from the fruits of Paeonia lactiflora. J Nat Prod 66: 759-763.

Touati A, Achour W, Cherif A, Hmida HB, Afif FB, Jabnoun S, Khrouf N, Hassen AB 2009. Outbreak of Acinetobacter baumannii in a neonatal intensive care unit: antimicrobial susceptibility and genotyping analysis. Ann Epidemiol 19: 372-378.

Uçkay I, Pittet D, Vaudaux P, Sax H, Lew D, Waldvogel F 2009. Foreign body infections due to Staphylococcus epidermidis. Ann Med 41: 109-119.

Viana FA, Pouliquen YBM, Andrade-Neto M, Santiago GMP, Pessoa ODL, Rodrigues-Filho E, Braz-Filho R 2004a. Complete ${ }^{1} \mathrm{H}$ and ${ }^{13} \mathrm{C}$ assignments for two new monodesmoside saponins from Pentaclethra macroloba (Wild.) Kuntze. Magn Reson Chem 42: 695-699.

Viana FA, Braz-Filho R, Pouliquen YBM, Neto MA, Santiago GMP, Rodrigues-Filho E 2004b. Triterpenoids saponins from stem bark of Pentaclethra macroloba. J Braz Chem Soc 15: 595-602.

\section{*Correspondence}

Ivana Correa Ramos Leal

Faculdade de Farmácia, Pólo Universitário, Universidade Federal do Rio de Janeiro, Campus Macaé

Rua Aluisio da Silva Gomes, 50, Granja dos Cavaleiros, 27930-

560 Macaé-RJ, Brazil

ivana@pharma.ufrj.br

Tel.+55212562 7248, +552125626795 